\title{
WYKORZYSTANIE INSTRUMENTÓW ZABEZPIECZAJĄCYCH W FIRMACH RODZINNYCH NOTOWANYCH NA GPW
}

\section{WSTĘP}

Deklarowanym celem wykorzystywania instrumentów pochodnych przez spółki publiczne jest ograniczanie ryzyka. Powszechnie przyjmuje się, iż skala wykorzystania instrumentów zabezpieczających jest ściśle związana z profilem działalności spółek, ich strukturą finansowania oraz ekspozycją na ryzyko walutowe, jednak w literaturze przedmiotu można spotkać również badania poświęcone innym czynnikom wpływającym na skłonność do wykorzystania instrumentów zabezpieczających.

Głównym celem naszego artykułu jest udzielenie odpowiedzi na pytania, czy występują istotne różnice w poziomie wykorzystywania instrumentów zabezpieczających pomiędzy spółkami rodzinnymi a nierodzinnymi notowanymi na GPW w Warszawie oraz czy czynniki determinujace wykorzystanie tych instrumentów różnią się pomiędzy obydwoma grupami spółek.

Pomiędzy spółkami rodzinnymi i nierodzinnymi występują dwie zasadnicze różnice, które moga wpływać na podejmowane decyzje w zakresie zabezpieczeń. Pierwsza z nich dotyczy dywersyfikacji portfeli poszczególnych akcjonariuszy, a druga - kosztów agencji pomiędzy zarządzającymi a właścicielami. Różnice te skłaniają do postawienia dwóch przeciwstawnych hipotez w zakresie stopnia wykorzystania instrumentów zabezpieczających w obydwu grupach spółek.

Akcjonariusze kontrolujacy spółki rodzinne - przedstawiciele rodzin - posiadają na ogół mniej zdywersyfikowane portfele aniżeli akcjonariusze kontrolujący spółki nierodzinne. Przyjmując za punkt wyjścia awersję do ryzyka, można przypuszczać, że spółki rodzinne charakteryzują się wyższą skłonnością do ograniczania ryzyka niż spółki nierodzinne. Za przejaw takich zachowań można uznać, obok wykorzystania instrumentów zabezpieczających, wyższy stopień dywersyfikacji działalności oraz niższy poziom zadłużenia spółek rodzinnych. Nasze dotychczasowe badania na grupie spółek notowanych na GPW w Warszawie nie potwierdzają jednak występowania istotnych różnic w zakresie stopnia dywersyfikacji i wykazują jednocześnie, że spółki rodzinne są bardziej zadłużone aniżeli spółki nierodzinne. Stawia to pod znakiem zapytania znaczenie dywersyfikacji indywidualnych portfeli akcjonariuszy jako 
czynnika wpływającego na działania podejmowane przez kontrolowane przez nich spółki w zakresie ograniczania ryzyka działalności.

Drugą istotną różnicą między firmami rodzinnymi a nierodzinnymi jest natężenie konfliktu interesów pomiędzy akcjonariuszami a zarządem, a co za tym idzie - skala kosztów agencji ${ }^{1}$. W firmach rodzinnych jest ona zdecydowanie mniejsza aniżeli w spółkach nierodzinnych. Ponieważ wykorzystanie instrumentów pochodnych nie zawsze musi być zgodne z interesem akcjonariuszy i może być traktowane jako przejaw kosztów agencji, można się spodziewać, że to w spółkach nierodzinnych, w których akcjonariat jest bardziej rozproszony, zarządzający w większym stopniu wykorzystują instrumenty zabezpieczające.

\section{HEDGING W FIRMACH RODZINNYCH - DOTYCHCZASOWE BADANIA EMPIRYCZNE ORAZ HIPOTEZY BADAWCZE}

Badania empiryczne poświęcone działaniom podejmowanym przez firmy rodzinne skutkującym ograniczaniem ryzyka zapoczątkowali R. Anderson i D. Reeb². W swojej pracy nie odnosili się bezpośrednio do wykorzystywania instrumentów zabezpieczających, lecz skoncentrowali się na interakcjach pomiędzy poziomem zadłużenia a stopniem dywersyfikacji, jako czynnikami wpływającymi na ryzyko działalności firm rodzinnych. Zainicjowali tym samym dyskusję nad szczególną rolą awersji do ryzyka w firmach rodzinnych, a co za tym idzie - skali i motywów wykorzystania narzędzi ograniczających ryzyko.

Jak dotąd badania empiryczne nad wykorzystaniem hedgingu w publicznych firmach rodzinnych nie są zbyt liczne i rozwijane są głównie w krajach, w których znaczenie firm rodzinnych jest istotne, takich jak Szwecja oraz Niemcy. N. Hagelin i inni przebadali 192 spółki (z czego ok. 60\% stanowiły firmy rodzinne) w okresie 1998-2001 notowane na giełdzie w Sztokholmie ${ }^{3}$. Nie znaleźli oni istotnych różnic w skali wykorzystania instrumentów zabezpieczających pomiędzy firmami rodzinnymi a nierodzinnymi. W obrębie firm rodzinnych zaobserwowali jednak negatywną zależność pomiędzy stopniem wykorzystania akcji uprzywilejowanych co do prawa głosu (dual-class shares) a skłonnością do wykorzystania hedgingu, znajdując tym samym potwierdzenie hipotezy, że stosowanie mechanizmów skutkujących powstaniem tzw. klina kontroli (control enhancing mechanisms) umożliwia ograniczenie ryzyka

\footnotetext{
${ }^{1}$ K. Lins, P. Volpin, H. F. Wagner, Does Family Control Matter? International Evidence from the 2008-2009 Financial Crisis, „Review of Financial Studies” 26, 2013, nr 10, s. 2583-2619.

${ }^{2}$ R. Anderson, D. Reeb, Founding - Family Ownership, Corporate Diversification, and Firm Leverage, ,Journal of Law and Economics” 46, 2003, nr 2, s. 653-684.

${ }^{3}$ N. Hagelin, M. Holmen, B. Pramborg, Family Ownership, Dual-Class Shares, and Risk Management, „Global Finance Journal” 16, 2006, nr 3, s. 283-301.
} 
na poziomie praw własności przy jednoczesnym zachowaniu kontroli nad spółka przez przedstawicieli rodzin.

Badania M. Ampenbergera i innych obejmowały 339 spółek (z czego 58\% stanowiły firmy rodzinne) notowanych na giełdzie we Frankfurcie w latach 2002-20064. Wynika z nich, że firmy rodzinne sa mniej skłonne do wykorzystywania instrumentów zabezpieczających niż firmy nierodzinne, co autorzy uzasadniają niższymi kosztami agencji pomiędzy właścicielami a zarządem spółek.

Przegląd wyników dotychczasowych badań w zakresie wykorzystania hedgingu przez firmy rodzinne oraz wyniki naszych wcześniejszych badań w zakresie innych niż hedging działań skutkujacych ograniczeniem ryzyka na poziomie spółki ${ }^{5}$ skłaniają nas do postawienia hipotezy, że awersja do ryzyka nie jest istotnym czynnikiem różnicujaccym spółki rodzinne i nierodzinne pod względem skłonności do wykorzystania hedgingu, a wręcz należy się spodziewać, że spółki rodzinne w mniejszym stopniu niż nierodzinne wykorzystuja instrumenty zabezpieczające ze względu na niższe koszty agencji.

\section{DEFINICJE, ŹRÓDŁA I METODY BADAWCZE}

Na potrzeby badań stworzyliśmy zero-jedynkową definicję firmy rodzinnej (FAM_DEF), która bezpośrednio nawiązuje do podejścia founding family. Za kryterium przynależności do grupy firm rodzinnych uznaliśmy: a) posiadanie przez założyciela firmy lub jego rodzinę co najmniej 25\% praw głosu lub b) udział przynajmniej jednego przedstawiciela rodziny w organach zarzadzajacych lub kontrolnych spółki. Gdy firma miała więcej niż jednego założyciela, braliśmy pod uwagę łaczne udziały rodzin wszystkich założycieli.

Posiadanie przez rodzinę określonej powyżej liczby praw głosu umożliwia jej istotny wpływ na podejmowanie kluczowych decyzji w spółce. Zgodnie z Kodeksem spółek handlowych podejmowanie decyzji strategicznych (takich jak np. zmiana statutu, zbycie przedsiębiorstwa lub jego części, czy rozwiązanie spółki) wymaga kwalifikowanej większości głosów na poziomie $75 \%$. Z kolei udział przedstawicieli rodziny w organach spółek niezależnie od posiadanych głosów może być przejawem przyznania indywidulanie oznaczonym akcjonariuszom przywilejów osobistych umożliwiających im znaczący wpływ na podejmowanie określonych decyzji dotyczących spółki.

Dodatkowo w naszych badaniach w celach kontrolnych uwzględniliśmy dwie dodatkowe zmienne związane ze statusem spółek rodzinnych: udział rodziny we własności (RODZ_CFR) oraz udział rodziny w łącznej liczbie głosów (RODZ_VR).

\footnotetext{
${ }^{4}$ M. Ampenberger et al., Family Firms, Agency Costs and Risk Aversion - Empirical Evidence from Diversification and Hedging Decisions, CEFS Working Paper Series 2008, nr 13.

5 T. Jewartowski, M. Kałdoński, Struktura kapitału i dywersyfikacja działalności spółek rodzinnych notowanych na GPW, „Prace Naukowe Uniwersytetu Ekonomicznego we Wrocławiu” 2012, nr 271, s. 265-278.
} 
Podstawową zmienną charakteryzująca skalę wykorzystania instrumentów zabezpieczających przez spółki jest relacja wartości nominalnej wszystkich rodzajów instrumentów pochodnych brutto do wartości aktywów spółki (HEDG_BR). Wyznaczając wartość brutto zabezpieczeń uwzględniliśmy sumę krótkich i długich pozycji w ramach instrumentów zabezpieczających przed ryzykiem kursowym (walutowym), stopy procentowej oraz surowcowym. Pozycje w walutach obcych przeliczaliśmy na złote po kursie NBP z końca danego roku. Dane o wartości poszczególnych zabezpieczeń pochodzą z informacji dodatkowych stanowiących załączniki do rocznych sprawozdań finansowych spółek objętych badaniem.

Alternatywnie uwzględniliśmy również zmienna charakteryzująca skalę wykorzystania instrumentów zabezpieczających (HEDG_NET), w przypadku której kompensowaliśmy długie i krótkie pozycje w ramach poszczególnych rodzajów ryzyka.

Poza tak wyznaczonymi zmiennymi ciagłymi wprowadziliśmy zmienna dualna: HEDG_0/1. Przyjmuje ona wartość 1 dla spółek wykorzystujących w danym roku jakiekolwiek instrumenty zabezpieczające i wartość 0 dla spółek, które nie wykorzystywały w danym roku żadnych zabezpieczeń.

Spośród wszystkich rodzajów instrumentów pochodnych najczęściej wykorzystywane sa instrumenty zabezpieczajace przed ryzykiem walutowym ${ }^{6}$. Z tego względu wyodrębniliśmy także zmienne, które charakteryzuja skalę (HEDG_WAL_BR) i skłonność (HEDG_WAL_0/1) do wykorzystania instrumentów walutowych przez spółki publiczne, przy czym skalę zabezpieczeń przed ryzykiem walutowym mierzyliśmy w ujęciu brutto.

Badania przeprowadzone zostały na niezbilansowanym panelu 105 spółek notowanych na GPW w Warszawie w latach 2006-2010. Pierwotnie próba badawcza obejmowała 140 spółek wchodzących w pierwszym kwartale 2011 r. w skład jednego z trzech indeksów: WIG20, mWIG40 oraz sWIG80. Z tak określonej próby wyeliminowaliśmy spółki z sektora finansowego oraz spółki, dla których nie były dostępne informacje o strukturze własności oraz założycielach. Ostatecznie zidentyfikowaliśmy 35 firm rodzinnych oraz 70 firm nierodzinnych.

Podstawowym źródłem danych finansowych - z wyłączeniem danych o instrumentach zabezpieczajacych - była baza Capital IQ firmy Standard\&Poors. Informacje o strukturze własności oraz dane dotyczące założycieli spółek pochodza przede wszystkim z bazy Notoria Serwis. W przypadku braku kompletnej informacji we wspomnianej bazie niezbędne dane uzupełnialiśmy o informacje pochodzace bezpośrednio z dokumentów statutowych oraz stron internetowych spółek.

Dla modeli, w których zmienna objaśniana miała charakter dualny, stosowaliśmy regresję logistyczna, a dla modeli, w których zmienna objaśniana miała charakter ciagły, wykorzystywaliśmy regresję tobitową? Uzasadnie-

\footnotetext{
${ }^{6}$ I. Tymoczko, Sposoby zabezpieczania się polskich przedsiębiorstw niefinansowych przed ryzykiem kursowym, „Bank i Kredyt” 40, 2009, nr 3, s. 71-92.

${ }^{7}$ Kompleksowe omówienie istoty modeli regresji logistycznej i tobitowej znaleźć można m.in. w: M. Gruszczyński (red.), Mikroekonometria. Modele i metody analizy danych indywidualnych, Wydawnictwo Wolters Kluwer, Warszawa 2012.
} 
niem wykorzystania modelu regresji tobitowej jest fakt, że w analizowanym okresie jedynie $40 \%$ jednostek objętych badaniem wykorzystywało instrumenty zabezpieczające. Jednocześnie dla modelu tobitowego oszacowane błędy standardowe uwzględniały korektę ze względu na heteroskedastyczność. Do oszacowania parametrów równań regresji wykorzystaliśmy program Gretl.

\section{WYNIKI BADAŃ EMPIRYCZNYCH}

Podstawowe zmienne objaśniane, zwiąane ze stopniem wykorzystania instrumentów zabezpieczających, oraz podstawowe zmienne objaśniające odnoszące się do statusu spółek rodzinnych zdefiniowane zostały w poprzednim punkcie. W modelach regresji uwzględniamy dodatkowo zmienne kontrolne, które - w świetle dotychczasowych badań empirycznych - mogą mieć wpływ na skłonność i skalę wykorzystania instrumentów zabezpieczających.

Zdecydowana większość dotychczasowych badań prowadzonych zarówno na grupie spółek polskich jak i zagranicznych (M. Geczy i inni; J. R. Graham, D. A. Rogers ${ }^{9}$; K. Klimczak ${ }^{10}$ ) potwierdza silną pozytywną zależność pomiędzy skalą działalności a skłonnością oraz stopniem wykorzystania przez spółki hedgingu. Innym czynnikiem determinującym wykorzystanie instrumentów zabezpieczających jest ekspozycja na ryzyko walutowe, wyrażana w badaniach empirycznych relacją przychodów zagranicznych do łącznych przychodów ze sprzedaży.

W naszych badaniach również uwzględniliśmy obie zmienne. Skalę działalności mierzymy logarytmem naturalnym aktywów spółek: LN(A), a ekspozycję na ryzyko walutowe - relacją przychodów zagranicznych do łącznych przychodów ze sprzedaży (FX_S/TS).

Dodatkowymi zmiennymi kontrolnymi uwzględnionymi w modelach regresji sa: poziom zadłużenia długoterminowego spółek (LTD/A), rentowność operacyjna (EBITDA/A), perspektywy wzrostu (MV/BV), udział najpłynniejszych aktywów w aktywach ogółem - (IK/A). Za miarę stopnia dywersyfikacji działalności przyjęliśmy powszechnie stosowany w literaturze przedmiotu z zakresu dywersyfikacji działalności indeks Hirschmana-Herfindahla (DYWERS_HHI), wyznaczony na bazie udziałów przychodów ze sprzedaży poszczególnych segmentów działalności spółek, definiowanych wg 2-cyfrowego kodu klasyfikacji $\mathrm{SIC}^{11}$. Indeks ten przyjmuje wartość w przedziale 0-1, przy czym wartość 1 oznacza brak dywersyfikacji, a stopień dywersyfikacji rośnie wraz ze spadkiem wartości indeksu HHI.

\footnotetext{
${ }^{8}$ M. Geczy, B. Minton, C. Schrand, Why Firms Use Currency Derivatives, ,Journal of Finance” 52, 1997, nr 4, s. 1323-1354.

9 J. R. Graham, D. A. Rogers, Do Firms Hedge in Response to Tax Incentives, „Journal of Finance" 57, 2002, nr 2, s. 815-839.

${ }^{10}$ K. Klimczak, Corporate Hedging and Risk Management Theory: Evidence from Polish Listed Companies, „The Journal of Risk Finance” 9, 2008, nr 1, s. 20-39.

${ }^{11}$ L. Lang, R. Stulz, Tobin's q, Corporate Diversification, and Firm Performance, „Journal of Political Economy" 102, 1994, s. 1248-1280.
} 
Ostatnia zmienna kontrolna dotyczy udziałów inwestorów instytucjonalnych posiadających więcej niż 5\% głosów (OUT_BLOCK_VR). Zmienna ta pośrednio wyraża stopnień ładu korporacyjnego.

W celu zbadania specyfiki firm rodzinnych w zakresie decyzji dotyczących wykorzystania instrumentów zabezpieczajacych dokonaliśmy podziału badanej populacji na dwie podgrupy: firmy rodzinne i nierodzinne. Podstawowe statystyki opisowe dla obu grup spółek zawiera tabela 1, prezentujacca również wyniki przeprowadzonych parametrycznych testów istotności różnic w wartościach średnich poszczególnych zmiennych pomiędzy grupa spółek rodzinnych a nierodzinnych ${ }^{12}$.

\section{Tabela 1}

Statystyki opisowe podstawowych zmiennych charakteryzujących próbę badawczą z podziałem na firmy rodzinne i nierodzinne

\begin{tabular}{|c|c|c|c|c|c|c|}
\hline \multirow{2}{*}{ Zmienne } & \multicolumn{2}{|c|}{ Razem } & \multicolumn{2}{|c|}{ Firmy nierodzinne } & \multicolumn{2}{|c|}{ Firmy rodzinne } \\
\hline & Średnia & Mediana & Średnia & Mediana & Średnia & Mediana \\
\hline HEDG_NET & 0,06 & 0,00 & 0,07 & 0,00 & $0,04^{* *}$ & 0,00 \\
\hline HEDG_BR & 0,07 & 0,00 & 0,08 & 0,00 & 0,06 & 0,00 \\
\hline $\begin{array}{l}\text { HEDG_ }_{-} \\
\text {WAL_BR }\end{array}$ & 0,05 & 0,00 & 0,06 & 0,00 & 0,05 & 0,00 \\
\hline FX_S/TS & 0,16 & 0,00 & 0,18 & 0,00 & $0,09 * * *$ & 0,00 \\
\hline $\begin{array}{l}\text { AKTYWA } \\
\text { (w mln zł) }\end{array}$ & 2887,50 & 979,60 & 3676,70 & 1074,70 & $1264,60^{* * *}$ & 785,90 \\
\hline LTD/A & 0,10 & 0,06 & 0,09 & 0,05 & $0,12^{* *}$ & 0,09 \\
\hline EBITDA/A & 0,10 & 0,10 & 0,10 & 0,10 & 0,10 & 0,09 \\
\hline MV/BV & 1,64 & 1,29 & 1,47 & 1,25 & $1,96^{* * *}$ & 1,41 \\
\hline $\mathrm{IK} / \mathrm{A}$ & 0,08 & 0,05 & 0,09 & 0,06 & 0,08 & 0,05 \\
\hline $\begin{array}{l}\text { DYWERS_ } \\
\text { HHI }\end{array}$ & 0,83 & 1,00 & 0,82 & 0,97 & 0,84 & 1,00 \\
\hline $\begin{array}{l}\mathrm{OUT}_{-} \\
\text {BLOCK_VR }\end{array}$ & 0,16 & 0,11 & 0,16 & 0,11 & 0,14 & 0,12 \\
\hline \multicolumn{7}{|c|}{$\begin{array}{l}\text { Liczba gwiazdek przy wartościach średnich dla spółek rodzinnych odnosi się do wyniku testu istot- } \\
\text { ności na różnicę w dwóch populacjach dla prób niezależnych (test t-Studenta dla prób niezależnych) } \\
\text { dla grupy spółek rodzinnych i nierodzinnych i oznacza odpowiednio: *** }-1 \% \text {, } * *-5 \% \text {. }\end{array}$} \\
\hline
\end{tabular}

Źródło: opracowanie własne.

Z powyższego zestawienia wynika, iż firmy rodzinne w mniejszym stopniu wykorzystują instrumenty zabezpieczajace niż spółki nierodzinne. Statystycznie istotną różnicę znaleźliśmy jednakże jedynie dla hedgingu całkowitego netto (kompensując pozycje długie i krótkie).

${ }^{12}$ Liczba gwiazdek przy wartościach średnich dla spółek rodzinnych odnosi się do wyniku testu istotności na różnicę w wartościach średnich dla obu grup spółek i oznacza odpowiednio: $* * *-1 \%, * *-5 \%$. 
Firmy rodzinne są mniejsze od firm nierodzinnych, charakteryzują się mniejsza ekspozycja na ryzyko walutowe, wyższym wskaźnikiem wartości rynkowej do księgowej oraz, o czym wspominaliśmy wcześniej, wyższym poziomem zadłużenia niż firmy nierodzinne.

Nie zaobserwowaliśmy istotnych różnic pomiędzy obydwoma grupami spółek w zakresie rentowności operacyjnej, poziomu płynnych aktywów, stopnia dywersyfikacji i udziału inwestorów instytucjonalnych.

Analizując odsetek spółek wykorzystujących instrumenty zabezpieczające, zaobserwowaliśmy istotne - potwierdzone odpowiednimi testami statystycznymi - różnice pomiędzy grupą spółek rodzinnych i nierodzinnych. W grupie spółek rodzinnych ok. $32 \%$ spośród nich wykorzystywało instrumenty zabezpieczające. Z kolei w przypadku spółek nierodzinnych wspomniany odsetek jest wyższy i wynosi $44 \%$.

Zaobserwowane różnice w skłonności i skali wykorzystania instrumentów zabezpieczających przez firmy rodzinne mogą wynikać z określonej przynależności sektorowej. Zbiorcze zestawienie dotyczące przynależności sektorowej spółek (jednostek obserwacji) objętych badaniem zawiera tabela 2.

\section{Tabela 2}

Liczebność firm rodzinnych i nierodzinnych w poszczególnych sektorach

\begin{tabular}{|l|c|c|c|}
\hline Pierwszy poziom klasyfikacji SIC & $\begin{array}{c}\text { Wszystkie } \\
\text { obserwacje }\end{array}$ & $\begin{array}{c}\text { Firmy } \\
\text { rodzinne }\end{array}$ & $\begin{array}{c}\text { Firmy } \\
\text { rodzinne (\%) }\end{array}$ \\
\hline Górnictwo & 15 & 5 & $33 \%$ \\
\hline Budownictwo & 49 & 14 & $29 \%$ \\
\hline Przemysł & 232 & 40 & $17 \%$ \\
\hline $\begin{array}{l}\text { Transport, komunikacja, } \\
\text { przedsiębiorstwa użyteczności publicznej }\end{array}$ & 67 & 20 & $30 \%$ \\
\hline Handel hurtowy & 35 & 25 & $71 \%$ \\
\hline Handel detaliczny & 29 & 15 & $52 \%$ \\
\hline Finanse, ubezpieczenia, nieruchomości & 35 & 20 & $57 \%$ \\
\hline Usługi & 55 & 35 & $64 \%$ \\
\hline Razem & $\mathbf{5 1 7}$ & $\mathbf{1 7 4}$ & $\mathbf{3 4 \%}$ \\
\hline
\end{tabular}

Źródło: opracowanie własne.

Z powyższego zestawienia wynika, że spółki rodzinne przeważają w sektorach stosunkowo mniej kapitałochłonnych (handel, usługi, nieruchomości), z kolei spółki nierodzinne przeważaja m.in. w sektorach: przemysłowym, budowlanym i wydobywczym. 


\section{Tabela 3}

Oszacowania parametrów regresji tobitowej w zakresie skali wykorzystania instrumentów zabezpieczających przez spółki notowane na GPW w latach 2006-2011 dla wybranych miar hedgingu

\begin{tabular}{|c|c|c|c|c|c|c|}
\hline \multirow{2}{*}{$\begin{array}{l}\text { Modele } \\
\text { regresji }\end{array}$} & \multicolumn{3}{|c|}{ Hedging calkowity netto [1-3] } & \multicolumn{3}{|c|}{ Hedging całkowity brutto [4-6] } \\
\hline & (1) & (2) & (3) & (4) & (5) & (6) \\
\hline \multirow{2}{*}{ Przecięcie } & $-0,4392^{* * *}$ & $-0,4281^{* * *}$ & $-0,4362^{* * *}$ & $-0,6743^{* * *}$ & $-0,6534^{* * *}$ & $-0,6646^{* * *}$ \\
\hline & $(0,0945)$ & $(0,0951)$ & $(0,0945)$ & $(0,1671)$ & $(0,1658)$ & $(0,1671)$ \\
\hline \multirow{2}{*}{ EBITDA/A } & 0,1612 & 0,1783 & 0,1757 & 0,0960 & 0,1184 & 0,1145 \\
\hline & $(0,1435)$ & $(0,1446)$ & $(0,1427)$ & $(0,1955)$ & $(0,1966)$ & $(0,1940)$ \\
\hline \multirow{2}{*}{$\mathrm{LN}(\mathrm{A})$} & $0,0453^{* * *}$ & $0,0432^{* * *}$ & $0,0441^{* * *}$ & $0,0678^{* * *}$ & $0,0648^{* * *}$ & $0,0661^{* * *}$ \\
\hline & $(0,0116)$ & $(0,0117)$ & $(0,0116)$ & $(0,0192)$ & $(0,0189)$ & $(0,0189)$ \\
\hline \multirow{2}{*}{$\mathrm{MV} / \mathrm{BV}$} & $0,0397 * * *$ & $0,0440 * * *$ & $0,0425^{* * *}$ & $0,0593^{* * *}$ & $0,0662^{* * *}$ & $0,0637^{* * *}$ \\
\hline & $(0,0133)$ & $(0,0139)$ & $(0,0137)$ & $(0,0208)$ & $(0,0225)$ & $(0,0219)$ \\
\hline \multirow{2}{*}{$\mathrm{IK} / \mathrm{A}$} & $-0,1203$ & $-0,1356$ & $-0,1210$ & $-0,3032$ & $-0,3283$ & $-0,3068$ \\
\hline & $(0,1503)$ & $(0,1514)$ & $(0,1512)$ & $(0,2221)$ & $(0,2262)$ & $(0,2236)$ \\
\hline \multirow{2}{*}{ FX_S/TS } & 0,0759 & 0,0764 & 0,0761 & 0,0977 & 0,0961 & 0,0962 \\
\hline & $(0,0567)$ & $(0,0570)$ & $(0,0566)$ & $(0,0732)$ & $(0,0733)$ & $(0,0727)$ \\
\hline \multirow{2}{*}{$\begin{array}{l}\text { OUT_BLOCK_ } \\
\text { VR }\end{array}$} & $-0,0637$ & $-0,0844$ & $-0,0821$ & $-0,0827$ & $-0,1116$ & $-0,1078$ \\
\hline & $(0,0847)$ & $(0,0854)$ & $(0,0855)$ & $(0,1174)$ & $(0,1204)$ & $(0,1203)$ \\
\hline \multirow{2}{*}{ LTD/A } & 0,1635 & 0,1713 & 0,1712 & 0,0845 & 0,0999 & 0,0985 \\
\hline & $(0,1139)$ & $(0,1135)$ & $(0,1138)$ & $(0,1549)$ & $(0,1526)$ & $(0,1532)$ \\
\hline \multirow{2}{*}{2010} & $-0,0507$ & $-0,0506$ & $-0,0499$ & 0,0676 & 0,0682 & 0,0670 \\
\hline & $(0,0402)$ & $(0,0401)$ & $(0,0399)$ & $(0,0735)$ & $(0,0731)$ & $(0,0727)$ \\
\hline \multirow{2}{*}{2009} & $-0,0612$ & $-0,0632^{*}$ & $-0,0621^{*}$ & 0,0721 & 0,0753 & 0,0736 \\
\hline & $(0,0375)$ & $(0,0376)$ & $(0,0376)$ & $(0,0631)$ & $(0,0629)$ & $(0,0625)$ \\
\hline \multirow{2}{*}{2008} & $0,0921^{* *}$ & $0,0945^{* *}$ & $0,0942^{* *}$ & $0,1601^{* *}$ & $0,1638^{* *}$ & $0,1622^{* *}$ \\
\hline & $(0,0378)$ & $(0,0379)$ & $(0,0378)$ & $(0,0656)$ & $(0,0657)$ & $(0,0653)$ \\
\hline \multirow{2}{*}{2007} & 0,0206 & 0,0224 & 0,0220 & $-0,0285$ & $-0,0314$ & $-0,0308$ \\
\hline & $(0,0347)$ & $(0,0347)$ & $(0,0347)$ & $(0,0632)$ & $(0,0635)$ & $(0,0632)$ \\
\hline \multirow{2}{*}{ DEF_RODZ } & $-0,0654^{* *}$ & & & $-0,0788^{*}$ & & \\
\hline & $(0,0303)$ & & & $(0,0446)$ & & \\
\hline \multirow{2}{*}{ RODZ_CFR } & & $-0,1619 * *$ & & & $-0,2194 * *$ & \\
\hline & & $(0,0644)$ & & & $(0,0963)$ & \\
\hline \multirow{2}{*}{ RODZ_VR } & & & $-0,1330 * *$ & & & $-0,1754 * *$ \\
\hline & & & $(0,0573)$ & & & $(0,0835)$ \\
\hline $\begin{array}{l}\text { Zmienne dualne } \\
\text { sektorów }\end{array}$ & TAK & TAK & TAK & TAK & TAK & TAK \\
\hline $\mathrm{N}$ & 469 & 469 & 469 & 469 & 469 & 469 \\
\hline
\end{tabular}

Źródło: opracowanie własne. 
W celu wyeliminowania problemu potencjalnego wpływu przynależności sektorowej na skłonność i skalę wykorzystania instrumentów zabezpieczających uwzględniamy w modelach regresji zmienne dualne charakteryzujące poszczególne sektory gospodarki według pierwszego poziomu klasyfikacji SIC (Standard Industrial Classification).

Oszacowania parametrów regresji tobitowej w zakresie skali wykorzystania instrumentów zabezpieczających przez spółki objęte badaniem zawiera tabela 3. Niezależnie od zastosowanej miary hedgingu zaobserwowaliśmy, że spółki rodzinne w mniejszym stopniu korzystaja z instrumentów zabezpieczających niż spółki nierodzinne. Zależność ta obowiązuje niezależnie od przyjętej zmiennej charakteryzujacej status spółki rodzinnej: dla wszystkich zmiennych w obydwu modelach regresji znaki parametrów są ujemne, a zależność jest istotna statystycznie w większości modeli na poziomie $5 \%$.

Spośród uwzględnionych zmiennych kontrolnych na skalę wykorzystania instrumentów zabezpieczających istotnie (pozytywnie) wpływają jedynie skala działalności oraz wskaźnik MV/BV.

Panelowa struktura danych pozwala zaobserwować zmiany skali wykorzystania instrumentów zabezpieczających w czasie. Spośród pięciu lat objętych analizą najwyższą skalę wykorzystania instrumentów pochodnych zaobserwowaliśmy dla 2008 r., co zbiega się w czasie z kryzysem finansowym. Z kolei zaobserwowany w latach 2008-2009 spadek wykorzystania instrumentów zabezpieczających jest konsekwencją ujawnienia szeroko opisywanego w czasopiśmiennictwie problemu tzw. toksycznych opcji ${ }^{13}$.

Tabela 4 przedstawia oszacowania tych samych parametrów, co poprzednia tabela, jednak dla regresji logistycznej. Wnioski z analizy danych zawartych w tabeli 4 są zasadniczo zbieżne z wnioskami płynącymi z oszacowania parametrów modeli tobitowych. Dodatkowo jednak model logitowy wskazuje na dodatnią zależność pomiędzy ekspozycją na ryzyko walutowe, mierzona udziałem przychodów zagranicznych w łącznych przychodach spółek (FX_S/ TS), a skłonnością do wykorzystania instrumentów zabezpieczających.

W kolejnym etapie ograniczyliśmy analizę skali i skłonności do wykorzystania instrumentów pochodnych zabezpieczajacych przed ryzykiem walutowym (tabela 5). Z danych zawartych w tabeli 5 płyną dwa zasadnicze wnioski:

- spośród zmiennych odnoszących się do statusu spółek jedynie udział rodziny we własności (RODZ_CFR) istotnie ujemnie wpływa na skłonność i skalę wykorzystania instrumentów zabezpieczajacych przed ryzykiem walutowym;

- zmienna kontrolna odnosząca się do ekspozycji na ryzyko walutowe istotnie dodatnio wpływa na skalę zabezpieczeń przed ryzykiem kursowym w każdym prezentowanym modelu, a zatem zależność ta - co jest logiczne jest istotniejsza na poziomie analizy zabezpieczeń walutowych niż wszystkich zabezpieczeń ujętych łącznie w miarach hedgingu.

13 P. Wiśniewski, Skutki opcji walutowych dla polskich przedsiębiorstw, „INFOS Zagadnienia Społeczno-Gospodarcze" 11, 2009, nr 58, s. 1-4. 


\section{Tabela 4}

Oszacowania parametrów regresji logistycznej w zakresie skłonności do wykorzystania instrumentów zabezpieczających przez spółki notowane na GPW w latach 2006-2011

\begin{tabular}{|c|c|c|c|}
\hline \multirow{2}{*}{ Modele regresji } & \multicolumn{3}{|c|}{ Hedging całkowity - zmienna dualna } \\
\hline & (1) & $(2)$ & $(3)$ \\
\hline \multirow{2}{*}{ Przecięcie } & $-4,8840 * * *$ & $-4,7660 * * *$ & $-4,8670 * * *$ \\
\hline & $(0,8647)$ & $(0,8724)$ & $(0,8631)$ \\
\hline \multirow{2}{*}{ EBITDA/A } & $-0,0034$ & 0,1706 & 0,1235 \\
\hline & $(1,4082)$ & $(1,4295)$ & $(1,3979)$ \\
\hline \multirow{2}{*}{$\mathrm{LN}(\mathrm{A})$} & $0,5279 * * *$ & $0,5103^{* * *}$ & $0,5205^{* * *}$ \\
\hline & $(0,1091)$ & $(0,1100)$ & $(0,1089)$ \\
\hline \multirow{2}{*}{ MV/BV } & $0,3032^{* *}$ & $0,3451^{* * *}$ & $0,3221^{* * *}$ \\
\hline & $(0,1192)$ & $(0,1269)$ & $(0,1233)$ \\
\hline \multirow{2}{*}{$\mathrm{IK} / \mathrm{A}$} & 0,7302 & 0,5810 & 0,6972 \\
\hline & $(1,2390)$ & $(1,2608)$ & $(1,2523)$ \\
\hline \multirow{2}{*}{ FX_S/TS } & $1,0845^{* *}$ & $1,0692^{* *}$ & $1,0873^{* *}$ \\
\hline & $(0,4674)$ & $(0,4753)$ & $(0,4692)$ \\
\hline \multirow{2}{*}{ OUT_BLOCK_VR } & 0,0690 & $-0,1437$ & $-0,0819$ \\
\hline & $(0,6934)$ & $(0,7084)$ & $(0,7086)$ \\
\hline \multirow{2}{*}{ LTD/A } & 0,3822 & 0,4707 & 0,4250 \\
\hline & $(0,9643)$ & $(0,9610)$ & $(0,9652)$ \\
\hline \multirow{2}{*}{2010} & $0,5959 *$ & $0,6003^{*}$ & $0,5843^{*}$ \\
\hline & $(0,3544)$ & $(0,3561)$ & $(0,3551)$ \\
\hline \multirow{2}{*}{2009} & $0,6841^{*}$ & $0,7096^{*}$ & $0,6872^{*}$ \\
\hline & $(0,3607)$ & $(0,3626)$ & $(0,3611)$ \\
\hline \multirow{2}{*}{2008} & $0,9512^{* * *}$ & $0,9835^{* * *}$ & $0,9606^{* * *}$ \\
\hline & $(0,3674)$ & $(0,3700)$ & $(0,3685)$ \\
\hline \multirow{2}{*}{2007} & 0,0266 & 0,0094 & 0,0117 \\
\hline & $(0,3757)$ & $(0,3801)$ & $(0,3770)$ \\
\hline \multirow{2}{*}{ DEF_RODZ } & $-0,5426 * *$ & & \\
\hline & $(0,2603)$ & & \\
\hline \multirow{2}{*}{ RODZ_CFR } & & $-1,4623 * * * *$ & \\
\hline & & $(0,5256)$ & \\
\hline \multirow{2}{*}{ RODZ_VR } & & & $-1,0660 * *$ \\
\hline & & & $(0,4888)$ \\
\hline $\begin{array}{l}\text { Zmienne dualne } \\
\text { sektorów }\end{array}$ & TAK & TAK & TAK \\
\hline $\mathrm{N}$ & 469 & 469 & 469 \\
\hline Pseudo $\mathrm{R}^{2}$ McFaddena & 0,1603 & 0,1655 & 0,1610 \\
\hline \multicolumn{4}{|c|}{$\begin{array}{l}\text { Liczba gwiazdek oznacza odpowiednio: }{ }^{* *} \text { - istotność na poziomie } 1 \%,{ }^{* *} \text { - istotność na pozio- } \\
\text { mie } 5 \%,{ }^{*} \text { - istotność na poziomie } 10 \% . \text { W nawiasach podane sa informacje o błędach standar- } \\
\text { dowych parametrów. }\end{array}$} \\
\hline
\end{tabular}

Źródło: opracowanie własne. 


\section{Tabela 5}

Oszacowania parametrów regresji tobitowej oraz logistycznej w zakresie skali oraz skłonności do wykorzystania instrumentów zabezpieczających przed ryzykiem walutowym przez spółki notowane na GPW w latach 2006-2011

\begin{tabular}{|c|c|c|c|c|c|c|}
\hline \multirow{2}{*}{$\begin{array}{l}\text { Modele } \\
\text { regresji }\end{array}$} & \multicolumn{3}{|c|}{ Tobit [1-3] } & \multicolumn{3}{|c|}{ Logit [4-6] } \\
\hline & (1) & (2) & (3) & (4) & (5) & (6) \\
\hline \multirow{2}{*}{ Przecięcie } & $-0,6167^{* * *}$ & $-0,6003^{* * * *}$ & $-0,6102^{* * *}$ & $-5,3182^{* * *}$ & $-5,2225^{* * * *}$ & $-5,3168^{* * *}$ \\
\hline & $(0,1394)$ & $(0,1378)$ & $(0,1389)$ & $(0,8827)$ & $(0,8897)$ & $(0,8825)$ \\
\hline \multirow{2}{*}{ EBITDA/A } & 0,0892 & 0,1020 & 0,0995 & 0,3181 & 0,4571 & 0,4022 \\
\hline & $(0,1779)$ & $(0,1793)$ & $(0,1774)$ & $(1,4885)$ & $(1,5081)$ & $(1,4787)$ \\
\hline \multirow{2}{*}{$\mathrm{LN}(\mathrm{A})$} & $0,0653^{* * *}$ & $0,0632^{* * *}$ & $0,0642^{* * *}$ & $0,5841^{* * *}$ & $0,5708^{* * *}$ & $0,5794 * * *$ \\
\hline & $(0,0173)$ & $(0,0171)$ & $(0,0171)$ & $(0,1111)$ & $(0,1119)$ & $(0,1111)$ \\
\hline \multirow{2}{*}{ MV/BV } & $0,0580^{* * * *}$ & $0,0626^{* * * *}$ & $0,0604^{* * *}$ & $0,3376^{* * *}$ & $0,3687 * * *$ & $0,3467 * * *$ \\
\hline & $(0,0177)$ & $(0,0189)$ & $(0,0185)$ & $(0,1182)$ & $(0,1241)$ & $(0,1211)$ \\
\hline \multirow{2}{*}{$\mathrm{IK} / \mathrm{A}$} & $-0,3677^{*}$ & $-0,3844^{*}$ & $-0,3695^{*}$ & $-0,0253$ & $-0,1535$ & $-0,0381$ \\
\hline & $(0,2009)$ & $(0,2044)$ & $(0,2022)$ & $(1,2863)$ & $(1,3080)$ & $(1,2936)$ \\
\hline \multirow{2}{*}{ FX_S/TS } & $0,1180^{*}$ & $0,1161^{*}$ & $0,1173^{*}$ & $1,1083^{* *}$ & $1,0898^{* *}$ & $1,1163^{* *}$ \\
\hline & $(0,0668)$ & $(0,0668)$ & $(0,0663)$ & $(0,4743)$ & $(0,4796)$ & $(0,4750)$ \\
\hline \multirow{2}{*}{ OUT_BLOCK_VR } & $-0,0464$ & $-0,0652$ & $-0,0608$ & 0,6326 & 0,4737 & 0,5352 \\
\hline & $(0,0945)$ & $(0,0969)$ & $(0,0968)$ & $(0,6974)$ & $(0,7100)$ & $(0,7117)$ \\
\hline \multirow{2}{*}{ LTD/A } & $-0,0478$ & $-0,0364$ & $-0,0398$ & 0,1358 & 0,2062 & 0,1484 \\
\hline & $(0,1437)$ & $(0,1416)$ & $(0,1422)$ & $(0,9632)$ & $(0,9600)$ & $(0,9655)$ \\
\hline \multirow{2}{*}{2010} & 0,0236 & 0,0241 & 0,0233 & 0,3949 & 0,4000 & 0,3846 \\
\hline & $(0,0621)$ & $(0,0617)$ & $(0,0614)$ & $(0,3580)$ & $(0,3591)$ & $(0,3581)$ \\
\hline \multirow{2}{*}{2009} & 0,0449 & 0,0470 & 0,0456 & 0,5816 & $0,6018^{*}$ & 0,5799 \\
\hline & $(0,0554)$ & $(0,0552)$ & $(0,0549)$ & $(0,3595)$ & $(0,3610)$ & $(0,3597)$ \\
\hline \multirow{2}{*}{2008} & $0,1351^{* *}$ & $0,1377^{* *}$ & $0,1363^{* *}$ & $0,8471^{* *}$ & $0,8722^{* *}$ & $0,8506^{* * *}$ \\
\hline & $(0,0579)$ & $(0,0580)$ & $(0,0577)$ & $(0,3637)$ & $(0,3660)$ & $(0,3643)$ \\
\hline \multirow{2}{*}{2007} & $-0,0474$ & $-0,0489$ & $-0,0486$ & $-0,1415$ & $-0,1524$ & $-0,1503$ \\
\hline & $(0,0598)$ & $(0,0602)$ & $(0,0599)$ & $(0,3804)$ & $(0,3843)$ & $(0,3810)$ \\
\hline \multirow{2}{*}{ DEF_RODZ } & $-0,0433$ & & & $-0,3814$ & & \\
\hline & $(0,0377)$ & & & $(0,2647)$ & & \\
\hline \multirow{2}{*}{ RODZ_CFR } & & $-0,1323^{*}$ & & & $-1,0597 * *$ & \\
\hline & & $(0,0795)$ & & & $(0,5217)$ & \\
\hline \multirow{2}{*}{ RODZ_VR } & & & $-0,0967$ & & & $-0,6943$ \\
\hline & & & $(0,0699)$ & & & $(0,4896)$ \\
\hline $\begin{array}{l}\text { Zmienne dual- } \\
\text { ne sektorów }\end{array}$ & TAK & TAK & TAK & TAK & TAK & TAK \\
\hline $\mathrm{N}$ & 469 & 469 & 469 & 469 & 469 & 469 \\
\hline $\begin{array}{l}\text { Pseudo } \mathrm{R}^{2} \\
\text { McFaddena }\end{array}$ & - & - & - & 0,1510 & 0,1540 & 0,1509 \\
\hline \multicolumn{7}{|c|}{$\begin{array}{l}\text { Liczba gwiazdek oznacza odpowiednio: } * * * \text { istotność na poziomie } 1 \%, * *-\text { istotność na pozio- } \\
\text { mie } 5 \%, * \text { - istotność na poziomie } 10 \% \text {. W nawiasach podane są informacje o błędach standar- } \\
\text { dowych parametrów. }\end{array}$} \\
\hline
\end{tabular}

Źródło: opracowanie własne. 


\section{Tabela 6}

Oszacowania parametrów regresji tobitowej w zakresie skali wykorzystania instrumentów zabezpieczających przez spółki notowane na GPW w latach 2006-2011 z podziałem na firmy rodzinne $(\mathrm{R})$ i nierodzinne $(\mathrm{NR})$

\begin{tabular}{|c|c|c|c|c|c|c|}
\hline \multirow{3}{*}{$\begin{array}{l}\text { Modele } \\
\text { regresji }\end{array}$} & \multicolumn{2}{|c|}{$\begin{array}{l}\text { Hedging brutto } \\
\text { calkowity } \\
{[1-2]}\end{array}$} & \multicolumn{2}{|c|}{$\begin{array}{l}\text { Hedging netto } \\
\text { całkowity } \\
{[3-4]}\end{array}$} & \multicolumn{2}{|c|}{$\begin{array}{c}\text { Hedging brutto } \\
\text { walutowy } \\
{[5-6]}\end{array}$} \\
\hline & $\mathrm{R}$ & NR & $\mathrm{R}$ & NR & $\mathrm{R}$ & NR \\
\hline & (1) & (2) & (3) & (4) & (5) & (6) \\
\hline \multirow{2}{*}{ Przecięcie } & $-0,9059 * * *$ & $-0,8998^{* * *}$ & $-0,7407^{* * *}$ & $-0,5048^{* * *}$ & $-0,7750 * * *$ & $-0,8144^{* * *}$ \\
\hline & $(0,2697)$ & $(0,2668)$ & $(0,1992)$ & $(0,1273)$ & $(0,2620)$ & $(0,2305)$ \\
\hline \multirow{2}{*}{ EBITDA/A } & 0,1758 & 0,3490 & 0,1705 & $0,3810^{*}$ & 0,0505 & 0,3245 \\
\hline & $(0,2817)$ & $(0,2935)$ & $(0,2197)$ & $(0,2236)$ & $(0,2858)$ & $(0,2686)$ \\
\hline \multirow{2}{*}{$\mathrm{LN}(\mathrm{A})$} & $0,1237^{* *}$ & $0,0508^{* *}$ & $0,0741^{* * * *}$ & $0,0322^{* *}$ & $0,1181^{* *}$ & $0,0544^{* * *}$ \\
\hline & $(0,0490)$ & $(0,0218)$ & $(0,0243)$ & $(0,0141)$ & $(0,0496)$ & $(0,0190)$ \\
\hline \multirow{2}{*}{$\mathrm{MV} / \mathrm{BV}$} & $0,0813^{* * *}$ & 0,0139 & $0,0600 * * * *$ & $-0,0038$ & $0,0784^{* * *}$ & 0,0083 \\
\hline & $(0,0238)$ & $(0,0375)$ & $(0,0165)$ & $(0,0250)$ & $(0,0241)$ & $(0,0315)$ \\
\hline \multirow{2}{*}{$\mathrm{IK} / \mathrm{A}$} & $-0,9152^{*}$ & $-0,2630$ & $-0,5984^{* *}$ & $-0,0355$ & $-0,8720 * *$ & $-0,3539$ \\
\hline & $(0,4744)$ & $(0,2958)$ & $(0,2930)$ & $(0,1965)$ & $(0,4420)$ & $(0,2590)$ \\
\hline \multirow{2}{*}{ FX_S/TS } & $0,5109 * * *$ & $-0,0393$ & $0,3393^{* * *}$ & $-0,0075$ & $0,4289^{* * *}$ & $-0,0281$ \\
\hline & $(0,1257)$ & $(0,0841)$ & $(0,1108)$ & $(0,0650)$ & $(0,1232)$ & $(0,0728)$ \\
\hline \multirow{2}{*}{ OUT_BLOCK_VR } & 0,3082 & $-0,0905$ & 0,1959 & $-0,0662$ & 0,2210 & $-0,0079$ \\
\hline & $(0,2212)$ & $(0,1257)$ & $(0,1608)$ & $(0,0893)$ & $(0,2158)$ & $(0,0940)$ \\
\hline \multirow{2}{*}{ LTD/A } & 0,3341 & 0,0236 & $0,3791^{* *}$ & 0,1143 & 0,0015 & $-0,0752$ \\
\hline & $(0,2404)$ & $(0,1893)$ & $(0,1853)$ & $(0,1316)$ & $(0,2516)$ & $(0,1733)$ \\
\hline \multirow{2}{*}{2010} & $-0,2325$ & $0,1758^{*}$ & 0,1176 & $-0,1109^{* *}$ & $-0,2544^{*}$ & $0,1215^{*}$ \\
\hline & $(0,1430)$ & $(0,0929)$ & $(0,0752)$ & $(0,0486)$ & $(0,1407)$ & $(0,0736)$ \\
\hline \multirow{2}{*}{2009} & $-0,2159$ & $0,1672^{* *}$ & 0,0276 & $-0,0830^{*}$ & $-0,2409^{*}$ & $0,1337^{* *}$ \\
\hline & $(0,1365)$ & $(0,0733)$ & $(0,0626)$ & $(0,0480)$ & $(0,1368)$ & $(0,0609)$ \\
\hline \multirow{2}{*}{2008} & $-0,1087$ & $0,2443^{* * *}$ & $0,1077^{*}$ & $0,0784^{*}$ & $-0,1106$ & $0,2049^{* * * *}$ \\
\hline & $(0,1314)$ & $(0,0742)$ & $(0,0609)$ & $(0,0442)$ & $(0,1235)$ & $(0,0624)$ \\
\hline \multirow{2}{*}{2007} & $-0,1868$ & 0,0407 & 0,0188 & 0,0136 & $-0,2039$ & 0,0245 \\
\hline & $(0,1354)$ & $(0,0622)$ & $(0,0533)$ & $(0,0413)$ & $(0,1361)$ & $(0,0540)$ \\
\hline $\begin{array}{l}\text { Zmienne dual- } \\
\text { ne sektorów }\end{array}$ & TAK & TAK & TAK & TAK & TAK & TAK \\
\hline $\mathrm{N}$ & 155 & 314 & 155 & 314 & 155 & 314 \\
\hline \multicolumn{7}{|c|}{$\begin{array}{l}\text { Liczba gwiazdek oznacza odpowiednio: *** - istotność na poziomie } 1 \%, * * \text { - istotność na pozio- } \\
\text { mie } 5 \%, * \text { - istotność na poziomie } 10 \% \text {. W nawiasach podane są informacje o błędach standar- } \\
\text { dowych parametrów. }\end{array}$} \\
\hline
\end{tabular}

Źródło: opracowanie własne. 
Pozostałe wnioski płynace z analizy skali i skłonności do wykorzystania instrumentów zabezpieczających przed ryzykiem walutowym są zatem zasadniczo zbieżne $\mathrm{z}$ wnioskami wyciagniętymi na podstawie analizy obejmującej wszystkie rodzaje zabezpieczeń.

W celu identyfikacji czynników różnicujących skalę i skłonność do wykorzystania instrumentów zabezpieczających przez grupę spółek rodzinnych i nierodzinnych skonstruowaliśmy modele regresji odrębnie dla każdej z tych grup (tab. 6).

Większą zgodność pomiędzy istotnością poszczególnych czynników a modelami teoretycznymi w zakresie determinant wykorzystania instrumentów zabezpieczajacych zaobserwowaliśmy dla spółek rodzinnych, dla której skala wykorzystania instrumentów zabezpieczających jest - bez względu na zastosowany model regresji - powiąana pozytywnie z rozmiarem prowadzonej działalności, wskaźnikiem MV/BV i ekspozycją na ryzyko walutowe.

Dodatkowo w grupie spółek rodzinnych zaobserwowaliśmy ujemna zależność pomiędzy poziomem płynnych aktywów (IK/A) a skalą wykorzystania instrumentów pochodnych. Zależność tę można próbować uzasadniać substytucyjnym charakterem rezerw gotówkowych względem instrumentów zabezpieczających poziom przepływów pieniężnych przed ryzykiem.

Ponadto dla jednego z modeli (w którym zmienna objaśniana jest hedging całkowity netto) zaobserwowaliśmy w grupie spółek rodzinnych pozytywną zależność pomiędzy wskaźnikiem zadłużenia a skalą zabezpieczeń.

Spośród wymienionych czynników w przypadku spółek nierodzinnych jedynym istotnym statystycznie czynnikiem wpływającym na skalę wykorzystania instrumentów zabezpieczających jest rozmiar prowadzonej działalności.

W kontekście odrębnej analizy determinant wykorzystania instrumentów pochodnych przez spółki rodzinne i nierodzinne warto wskazać na dużo większe zmiany aktywności w zakresie skali wykorzystywania instrumentów zabezpieczajacych w czasie.

W ramach dodatkowego testu te same postaci modeli regresji zastosowaliśmy do opóźnionych zmiennych objaśniających. Test ten potwierdził odrębność czynników determinujących wykorzystanie instrumentów zabezpieczających pomiędzy spółkami rodzinnymi i nierodzinnymi.

\section{PODSUMOWANIE}

Przeprowadzone badania miały na celu udzielenie odpowiedzi na pytanie, czy pomiędzy grupa spółek rodzinnych a grupa spółek nierodzinnych występują istotne różnice w zakresie skłonności, skali oraz czynników wpływających na wykorzystanie instrumentów zabezpieczających. Z naszych badań wynika, że publiczne spółki rodzinne w mniejszym stopniu wykorzystują instrumenty zabezpieczające w stosunku do spółek nierodzinnych, co jedynie częściowo wynika z ich innej przynależności sektorowej. 
Powyższe skłania do poszukiwań innych czynników różnicujących wykorzystanie instrumentów zabezpieczających w obydwu grupach spółek. W naszych badaniach uwzględniliśmy m.in. czynniki bezpośrednio wpływające na ekspozycję spółek na ryzyko, takie jak skala przychodów zagranicznych czy poziom dźwigni finansowej. Ku naszemu zaskoczeniu jedynie w grupie spółek rodzinnych znaleźliśmy pozytywną zależność pomiędzy tymi zmiennymi a skala wykorzystania instrumentów zabezpieczajacych. Dodatkowo zaobserwowaliśmy silniejszą reakcję spółek nierodzinnych w zakresie skali wykorzystywania instrumentów zabezpieczających na zmianę warunków zewnętrznych: poziom zabezpieczeń ulegał w tej grupie większym wahaniom w czasie.

Wszystkie te obserwacje pośrednio weryfikuja postawiona przez nas hipotezę, że awersja do ryzyka nie jest istotnym czynnikiem różnicującym spółki rodzinne i nierodzinne pod względem skłonności do wykorzystania hedgingu, tzn. spółki rodzinne nie cechują się silniejszą awersją do ryzyka niż spółki nierodzinne, zgodnie z powszechnie utartym poglądem. Wyniki badań potwierdzają jednocześnie, że na obserwowane różnice w skłonności i skali wykorzystania instrumentów zabezpieczających wpływ maja problemy agencji, silniejsze dla spółek nierodzinnych. Do takich wniosków skłaniają nas zaobserwowane różnice w samej skali wykorzystania instrumentów zabezpieczających (wyższa dla spółek nierodzinnych), a również, czy nawet przede wszystkim, brak istotnych zależności pomiędzy czynnikami charakteryzującymi ekspozycję na ryzyko (takimi jak udział sprzedaży zagranicznej w przychodach czy poziom dźwigni finansowej) a skalą zabezpieczeń w grupie spółek nierodzinnych. Przeprowadzone przez nas badania wskazują wyraźnie, że spółki rodzinne stosują instrumenty zabezpieczające w mniejszej skali, a jeżeli już stosuja, to związane jest to w większym stopniu z ich faktyczną ekspozycją na ryzyko.

dr Tomasz Jewartowski

Uniwersytet Ekonomiczny w Poznaniu

tomasz.jewartowski@ue.poznan.pl

dr Michat Katdoński

Uniwersytet Ekonomiczny w Poznaniu

michal.kaldonski@ue.poznan.pl

\section{USE OF DERIVATIVES BY FAMILY FIRMS LISTED ON WARSAW STOCK EXCHANGE}

Summary

On the basis of an unbalanced panel of 105 public companies listed on Warsaw Stock Exchange in the period 2006-2010 we document that, on average, family firms are less likely to use hedging instruments and they use them less extensively than non-family firms. Moreover, for family firms we observe significantly stronger relation between risk exposure measures such as foreign sales percentage or financial leverage and the scale of hedging instruments used. Our findings do not confirm the conventional wisdom of above-average risk-aversion of family firms. The differences between family and non-family firms in the use of hedging instruments should be rather explained on the basis of agency theory and agency costs. 
Copyright of Journal of Law, Economics and Sociology is the property of Faculty of Law and Administration of Adam Mickiewicz University in Poznan and its content may not be copied or emailed to multiple sites or posted to a listserv without the copyright holder's express written permission. However, users may print, download, or email articles for individual use.

Właścicielem praw autorskich do „Ruchu Prawniczego, Ekonomicznego i Socjologicznego” jest Wydział Prawa i Administracji Uniwersytetu im. Adama Mickiewicza w Poznaniu. Zawartość czasopisma nie może być kopiowana, przesyłana do innych stron internetowych bądź zamieszczana na blogach bez pisemnej zgody wydawcy. Niemniej artykuły można drukować, kopiować lub przesyłać w formie elektronicznej na własny użytek. 